\title{
RMo1 Confers Blast Resistance in Barley and Is Located within the Complex of Resistance Genes Containing Mla, a Powdery Mildew Resistance Gene
}

\author{
Tsuyoshi Inukai, ${ }^{1}$ M. Isabel Vales, ${ }^{2}$ Kiyosumi Hori, ${ }^{3}$ Kazuhiro Sato, ${ }^{3}$ and Patrick M. Hayes ${ }^{2}$ \\ ${ }^{1}$ Graduate School of Agriculture, Hokkaido University, Sapporo, Japan; ${ }^{2}$ Department of Crop and Soil Science, Oregon \\ State University, Corvallis, Oregon, U.S.A.; ${ }^{3}$ Research Institute for Bioresources, Okayama University, Kurashiki, Japan
}

Submitted 28 February 2006. Accepted 17 April 2006.

\begin{abstract}
Isolates of Magnaporthe oryzae (the causal agent of rice blast disease) can infect a range of grass species, including barley. We report that barley Hordeum vulgare cv. Baronesse and an experimental line, BCD47, show a range of resistance reactions to infection with two rice blast isolates. The complete resistance of Baronesse to the isolate Ken 54-20 is controlled by a single dominant gene, designated $R M o 1$. RMo1 mapped to the same linkage map position on chromosome $1 \mathrm{H}$ as the powdery mildew resistance locus Mla and an expressed sequence tag $(\mathbf{k 0 4 3 2 0})$ that corresponds to the barley gene 711N16.16. A resistance quantitative trait locus (QTL), at which Baronesse contributed the resistance allele, to the isolate Ken 53-33 also mapped at the same position as RMo1. Synteny analysis revealed that a corresponding region on rice chromosome 5 includes the bacterial blight resistance gene $x a 5$. These results indicate that a defined region on the short arm of barley chromosome $1 \mathrm{H}$, including $\mathrm{RMo1}$ and $M l a$, harbors genes conferring qualitative and quantitative resistance to multiple pathogens. The partial resistance of BCD47 to Ken53-33 is determined by alleles at three QTL, two of which coincide with the linkage map positions of the mildew resistance genes $m l o$ and $M l f$.
\end{abstract}

Additional keywords: Blumeria graminis f. sp. hordei, Oryza sativa.

Blast disease, caused by Magnaporthe oryzae (Couch and Kohn 2002), is one of the most important diseases of rice (Oryza sativa). Local epidemics of blast disease have been reported in several other grass species. For instance, blast disease was reported in barley (Hordeum vulgare) in western and southern Japan (Kawai et al. 1979; Matsumoto and Mogi 1979) and northern Thailand (Sato et al. 2001), in wheat (Triticum aestivum) fields in the Parana and Mato Grosso do Sul states of Brazil (Urashima et al. 2004), in perennial ryegrass (Lolium perene) fields in the mid-Atlantic states of the U.S.A. (Williams et al. 2001), and in Italian ryegrass (Lolium multiflorum) fields in southwestern Japan (Miura et al. 2005). Although reports for blast resistance in these grass species are limited, at least some of these species possess qualitative, quantitative, or both, resistance genes to the blast fungus.

In barley, Yaegashi (1988) identified a single dominant gene (PHR-1) conditioning resistance to a barley blast isolate in the

Tsuyoshi Inukai and M. Isabel Vales contributed equally to this work.

Corresponding author: P. M. Hayes;

E-mail: patrick.m.hayes@oregonstate.edu cultivars Daisen Gold and Miho Golden. We have reported that the experimental line TR306 carried resistance quantitative trait locus (QTL) alleles to rice blast (Chen et al. 2003; Sato et al. 2001). Recent studies identified single dominant genes conferring resistance to a rice blast isolate in the grass species Brachypodium distachyon as well as resistance to an Italian ryegrass blast isolate in Italian ryegrass (Miura et al. 2005; Routledge et al. 2004). In wheat, Urashima and associates (2004) found that some cultivars in Brazil showed different degrees of resistance to wheat blast isolates. In order to effectively breed for blast resistance in these species more information about the amount of genetic variation of resistance and the inheritance of this resistance will be necessary.

Plant disease-resistance genes often cluster in particular chromosomal regions. In rice, Wisser and associates (2005) identified several chromosomal segments associated with both qualitative and quantitative resistance to multiple pathogens. According to the integrated map of these disease-resistance genes in rice, blast resistance QTL are often colocalized with blast resistance $P i$ loci or QTL for resistance to other pathogens causing diseases such as sheath rot, sheath blight, and bacterial blight, or both. Resistance gene analogs of the nucleotide-binding site-leucine-rich repeat (NBS-LRR) class were also shown to colocalize with the cluster of $P i$ loci and blast resistance QTL, suggesting that these $R$ genes could be candidates for major genes and QTL (Wisser et al. 2005). In barley, clustering of major resistance genes and resistance QTL has also been reported (Williams 2003).

We have previously mapped quantitative and qualitative genes conferring resistance to multiple pathogens in a doubled haploid (DH) mapping population of barley derived from the $F_{1}$ of the cross of Baronesse and BCD47 (Vales et al. 2005). In an ongoing screen of barley germplasm for blast resistance, we found that Baronesse and BCD47 showed qualitative or quantitative resistance, or both, to two rice blast isolates. In order to identify these blast resistance genes and to determine their linkage relationships with previously mapped resistance genes, we used the same population to determine the location of the blast resistance genes in Baronesse and BCD47. Due to the availability of mapped barley expressed sequence tag (EST) markers, we were able to extend our mapping to rice in order to determine if there is synteny between blast resistance genes in the two species.

\section{RESULTS}

Disease resistance phenotypes.

Barley genotypes Baronesse and BCD47 showed contrasting disease reactions to inoculation with the two rice blast isolates. 
An almost completely resistant reaction was observed for Baronesse inoculated with Ken54-20 (Fig. 1; Table 1). When inoculated with Ken54-20, Baronesse occasionally developed a few susceptible-type lesions. In contrast, Baronesse had a moderately susceptible reaction to inoculation with Ken53-33 (Fig. 1; Table 1). BCD47 showed moderately susceptible reactions to inoculation with both isolates (Fig. 1; Table 1). Because the levels of disease severity in Harrington and the rice susceptible controls were not significantly different between the two isolates (Fig. 1; Table 1), the different reactions of Baronesse to the two isolates are attributed to race-specific resistance in Baronesse rather than to differences in isolate aggressiveness.

\section{Mapping the qualitative resistance in Baronesse.}

In order to investigate the inheritance of race-specific blast resistance in Baronesse, the $100 \mathrm{DH}$ lines derived from the cross of BCD47 and Baronesse were inoculated with Ken5420. The phenotypic frequency distribution for resistance score was discontinuous (Fig. 2A), and the ratio of resistant to susceptible lines was $46: 54$. This observed ratio shows good fit to the expected 1:1 ratio for a single gene in a $\mathrm{DH}$ population $\left(\chi^{2}\right.$ $=0.64, P>0.5)$. Therefore, we conclude that the resistance of Baronesse to Ken54-20 is determined by a single major gene.

Table 1. Disease severity of barley and rice cultivars or lines inoculated with two rice blast isolates

\begin{tabular}{lcc}
\hline & \multicolumn{2}{c}{ Isolate } \\
\cline { 2 - 3 } Cultivar or line and cross & Ken 54-20 & Ken 53-33 \\
\hline Barley & & \\
Baronesse & $0.6 \pm 0.5^{\mathrm{a}}$ & $2.6 \pm 0.7$ \\
BCD47 & $2.5 \pm 1.0$ & $2.6 \pm 0.8$ \\
Harrington & $4.2 \pm 1.1$ & $4.1 \pm 1.0$ \\
BCD12 & $4.2 \pm 0.8$ & $\ldots{ }^{\mathrm{b}}$ \\
Baronesse $\times$ BCD47 $\mathrm{F}_{1}$ & 0 & $\ldots$ \\
Baronesse $\times$ BCD12 $\mathrm{F}_{1}$ & $0.3 \pm 0.6$ & $\ldots$ \\
Rice & & \\
Shin2 & $2.5 \pm 0.7$ & $3.0 \pm 0.4$ \\
Aichi asahi & $2.6 \pm 0.5$ & $2.6 \pm 0.5$ \\
\hline
\end{tabular}

${ }^{a}$ Average disease severity scores for five seedlings \pm standard deviation.

${ }^{\mathrm{b}}$ No data because of insufficient seed for phenotypic evaluation.

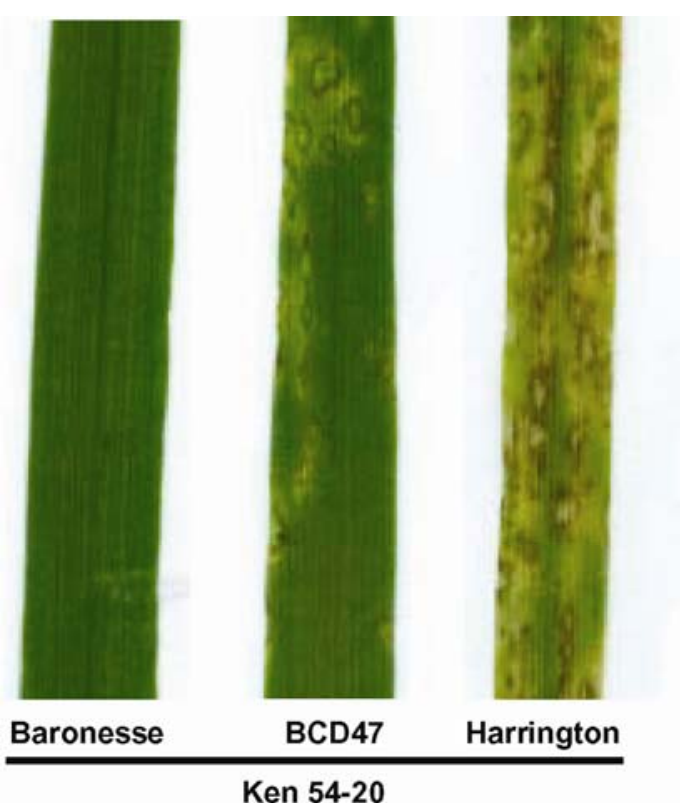

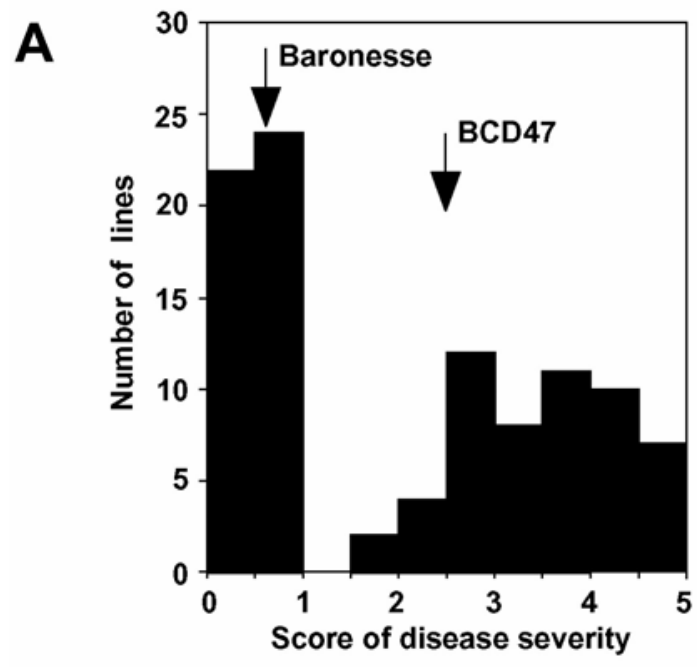

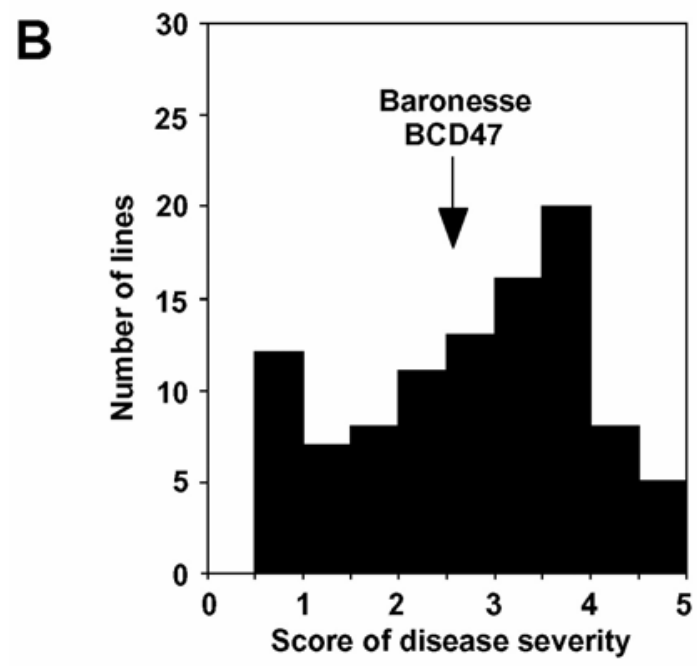

Fig. 2. Phenotypic frequency distributions for disease score in the 100 doubled haploid progeny derived from the $\mathrm{F}_{1}$ of BCD $47 \times$ Baronesse inoculated with rice blast isolates A, Ken 54-20 or B, Ken 53-33. The average scores of parents are indicated by arrows.

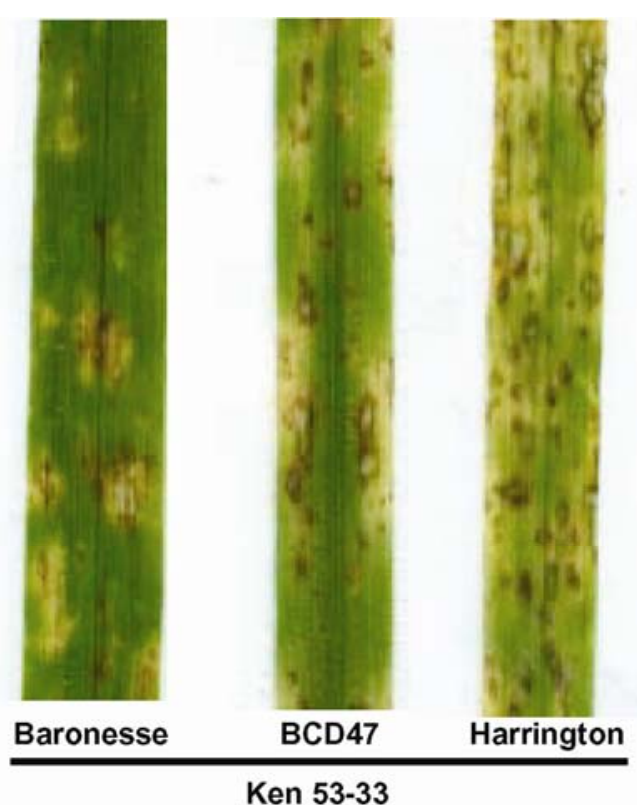

Fig. 1. Reactions of the barley genotypes Baronesse, BCD47, and Harrington to the rice blast isolates Ken 54-20 and Ken 53-33. Seedlings were inoculated at the 1.5- to tw2-leaf stage. After 5 to 6 days following inoculation, the samples were temporally fixed in $70 \%$ ethanol and were photographed. 
Since the reactions of the $\mathrm{F}_{1}$ of Baronesse $\times$ BCD47 and Baronesse $\times$ BCD12 to Ken54-20 were almost the same as those of Baronesse (Table 1), this resistance is dominant. Based on these results, the race-specific resistance gene in Baronesse was designated as RMo1 (resistance to Magnaporthe oryzae 1). $R M o 1$ cosegregates with the sequence-tagged site marker Mlax, based on the published sequence of Mla12, a gene that confers resistance to powdery mildew (Blumeria graminis $\mathrm{f}$. sp. hordei). It also cosegregates with the microsatellite marker GMS21, and these findings position $R M o 1$ on the short arm of chromosome $1 \mathrm{H}$ (Fig. 3). It is not possible to estimate genetic distances between $R M o 1$ and the cosegregating markers, given a mapping population size of $100 \mathrm{DH}$ lines. Per Hanson (1959), the 95\% confidence interval for the genetic distance between $R M o 1$ and the cosegregating markers is $3.0 \mathrm{cM}$.

Baronesse is reported to carry Mla 3 resistance, based on reaction to inoculation with differential isolates (Dreiseitl 2003; Hovmøller et al. 2000). Mla12 and Mla3 are members of the Mla complex locus, and based on linkage data, RMo1 cosegregates with Mla. In order to increase marker density in this region and establish a basis for synteny comparisons with rice, eight additional barley EST markers were mapped. Of these,

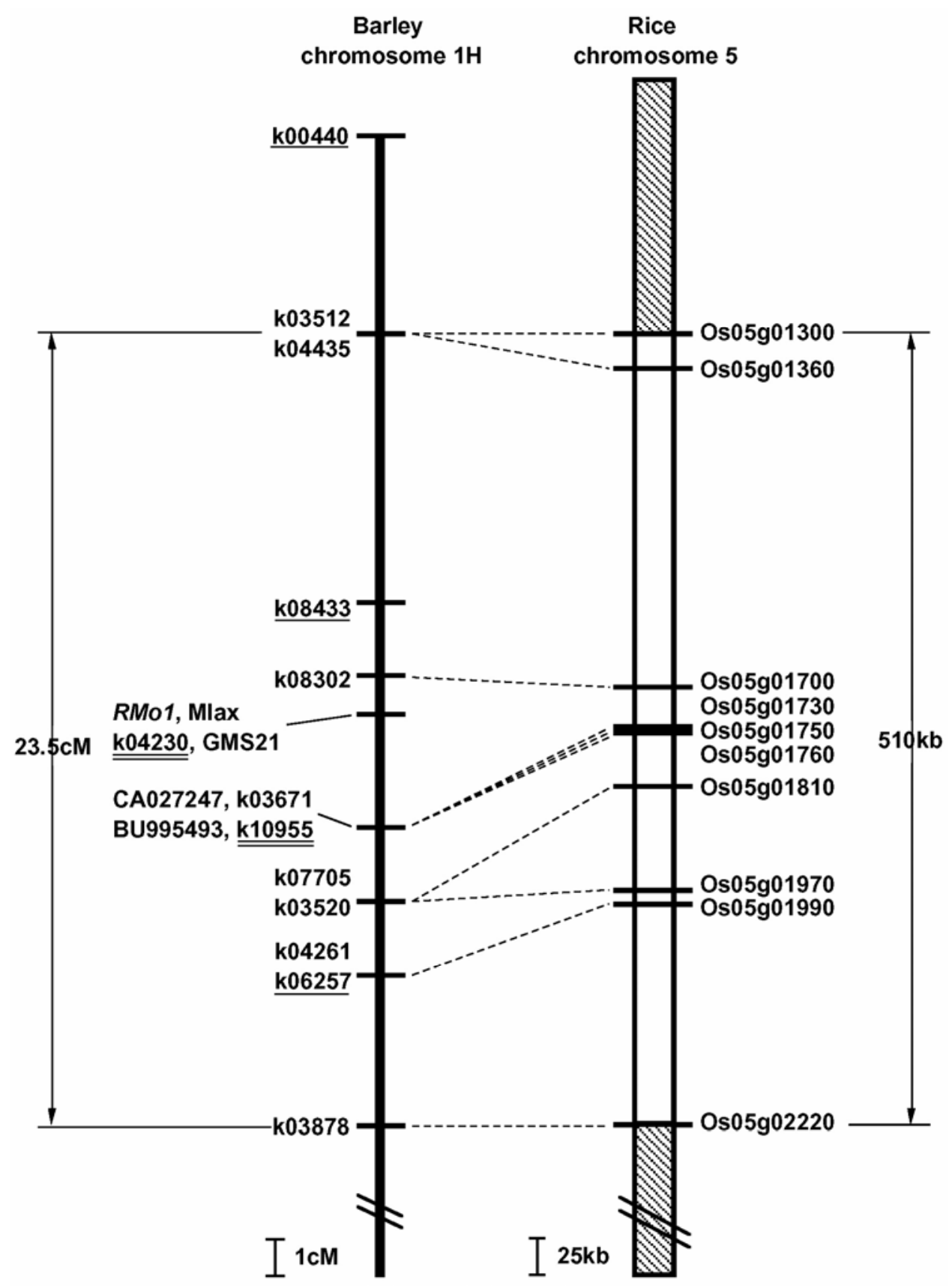

Fig. 3. Chromosomal position of the RMo1 gene conferring nearly complete resistance to rice blast isolate Ken 54-20. Synteny between the region of barley chromosome $1 \mathrm{H}$ containing RMo1 and the subtelomeric region of rice chromosome 5 is indicated. The genetic map of barley chromosome $1 \mathrm{H}$ and the physical map of rice chromosome 5 are aligned. In the barley genetic map, the "k - loci", CA027247, and BU995493 are barley expressed sequence tag (EST)-based markers. Mlax is the sequence-tagged site marker based on the published sequence of Mla7, and GMS21 is a microsatellite marker (Vales et al. 2005). Ten of the 15 EST markers showed high homology to genes in the subtelomeric 510-kb region of rice chromosome 5, and the order of these genes is conserved. The underlined markers did not show any homology to rice genome sequences. The markers double-underlined showed homology to rice genes located in other chromosomal regions. In the rice physical map, the syntenic region is shown in white. Locus designations are according to the descriptions in The Institute for Genomic Research rice genome database. 
EST marker k04230 cosegregated with RMo1 (Fig. 3). A BLAST homology search shows that $\mathrm{k} 04230$ corresponds to the barley gene $711 \mathrm{~N} 16.16(e$ value $=0)$, which is reported to be $190 \mathrm{~kb}$ from Mla (Wei et al. 2002). This establishes the position of RMo1 as lying within or near the Mla-711N16.16 interval.

We used this information to explore the syntenous region in rice, based on The Institute for Genomic Research (TIGR) Rice Genome Annotation database. Ten of 15 barley EST markers in the vicinity of $R M o 1$ showed high homology to sequences on rice chromosome 5 . There is colinearity of gene order between the 23.5 -cM region extending from $\mathrm{k} 03512$ to $\mathrm{k} 03878$ in barley chromosome $1 \mathrm{H}$ and the $510-\mathrm{kb}$ region from the gene Os05g01300 to Os05g02220 in the end of rice chromosome 5 (Fig. 3). Barley EST markers k08302 and CA027247, which flank RMo1, also mapped in silico to the expected position on rice chromosome 5 (Fig. 3), and the physical distance between the predicted rice orthologs (Os05g01700 and Os05g01730) is approximately $15 \mathrm{~kb}$ (Fig. 4). According to the annotation data in the TIGR rice genome database, there are two genes in this region, a bacterial blight resistance gene $x a 5$ (Os05g01710), which encodes the gamma subunit of transcription factor IIA (TFIIA $\gamma$ ) (Iyer and McCouch 2004) and a hypothetical protein gene (Os05g01720). Neither of these genes shows any homology to the 261-kb sequence containing Mla and 711N16.16, indicating a lack of barleyrice microsynteny in the regions flanked by $\mathrm{k} 08302 /$ Os05g01700 and CA027247/Os05g01730.

\section{Mapping quantitative resistance genes.}

The average disease scores for both Baronesse and BCD47 when inoculated with Ken53-33 were 2.6 (Table 1). This disease severity is lower than that of the highly susceptible cultivar Harrington (score $=4.1$ ), indicating that both Baronesse and BCD47 have partial resistance to this rice blast isolate. In order to identify the genetic basis of this resistance, the mapping population was inoculated with Ken53-33. The phenotypic frequency distribution of disease scores was continuous (Fig. 2B). A large-effect QTL, in which Baronesse contributed the resistance allele was mapped to the same region as RMo1. Three lesser-effect QTL, in which BCD47 contributed resistance alleles were located on chromosomes $3 \mathrm{H}, 4 \mathrm{H}$, and $7 \mathrm{H}$ (Table 2; Fig. 5). The 4H QTL mapped to the k01150 to HvMLO3 interval (Table 2); k01150 and HvMLO3 are tightly linked $(1.1 \mathrm{cM})$. HvMLO3 is a simple sequence repeat marker based on the sequence of mlo (Ramsay et al. 2000), which confers broad spectrum resistance to powdery mildew. The other resistance QTL, in which BCD47 contributes the resistance allele, maps to the Ris44 to Bmac156 interval on $7 \mathrm{H}$. According to Schönfeld and associates (1996), the powdery mildew resistance gene $M l f$, derived from a wild barley (Hordeum vulgare subsp. spontaneum), is located on the long arm of chromosome $7 \mathrm{H}$. The log of the likelihood ratio (LOD) peak of the rice blast QTL is $15.0 \mathrm{cM}$ distal from Ris44; Mlf is estimated to $9.4 \mathrm{cM}$ from Ris44, based on previous reports (Graner et al. 1994; Schönfeld et al. 1996)) (Fig. 5).

\section{DISCUSSION}

Barley cultivar Baronesse shows nearly complete and racespecific resistance to the rice blast fungus. This novel resistance is determined by a single dominant gene-RMo1-located on chromosome 1H. RMo1 cosegregates with Mla and $711 \mathrm{~N} 16.16$, which is approximately $190 \mathrm{~kb}$ from Mla, according to Wei and associates (2002). These authors reported that 15 of the 32 predicted genes in the $261-\mathrm{kb}$ region sequenced around Mla are associated with defense responses to pathogens. These genes were classified into five gene families: three coiled coil (CC)-NBS-LRR $R$ gene homolog families, one of which includes $M l a$, one chymotrypsin inhibitor $2(\mathrm{Cl} 2)$ fam-

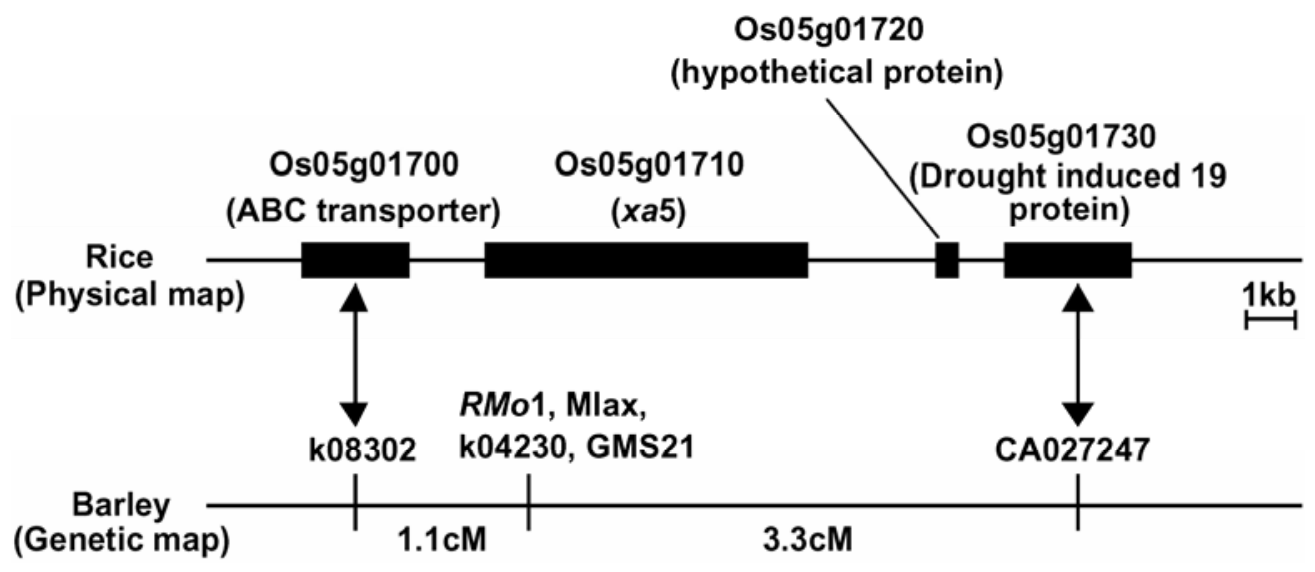

Fig. 4. Genome structure of the rice region containing genes corresponding to barley expressed sequence tag markers k08432 and CA027247.

Table 2. Resistance quantitative trait loci (QTL) to rice blast isolate Ken 53-33 detected in the BCD47 × Baronesse doubled haploid population using composite interval mapping

\begin{tabular}{|c|c|c|c|c|c|}
\hline \multirow[b]{2}{*}{ Chromosome } & \multicolumn{2}{|c|}{ QTL peak position } & \multirow[b]{2}{*}{ LOD $^{b}$} & \multirow[b]{2}{*}{$\mathbf{R}^{2}(\%)^{\mathbf{c}}$} & \multirow[b]{2}{*}{ Additive effect ${ }^{d}$} \\
\hline & Marker interval & Distance $(\mathbf{c M})^{\mathrm{a}}$ & & & \\
\hline $1 \mathrm{H}$ & Mlax to CA027247 & 0.0 & 25.0 & 60.7 & 1.8 \\
\hline $3 \mathrm{H}$ & Bmag603 to Bmag225 & 15.5 & 3.1 & 5.2 & -0.5 \\
\hline $4 \mathrm{H}$ & k01150 to HvMLO3 & 0.0 & 3.0 & 4.1 & -0.5 \\
\hline $7 \mathrm{H}$ & Ris44 to Bmac156 & 15.0 & 4.2 & 9.6 & -0.7 \\
\hline
\end{tabular}

${ }^{\mathrm{a}}$ Distance of QTL peak position from the left side marker.

${ }^{\mathrm{b}}$ Log of the likelihood ratio at the QTL peak position.

${ }^{\mathrm{c}}$ Percentage of phenotypic variation explained by the QTL.

${ }^{\mathrm{d}}$ Positive or negative value indicates that Baronesse or BCD47, respectively, contributed the allele for quantitative resistance to Ken53-33. 
ily, and one chemically induced family. It is likely that $R M o 1$ is a member of one of these classes of $R$ genes, but proof will require systematic isolation of all candidate genes.

Genes in the NBS-LRR class have been shown to confer resistance to fungi, bacteria, viruses, and nematodes (HammondKosack and Parker 2003). The rice blast resistance genes Pib and $P i 9$ are members of this class (Qu et al. 2006; Wang et al.
1999). $\mathrm{Cl} 2$ genes belong to the potato inhibitor 1 family of Ser protease inhibitors (Wei et al. 2002), which function in resistance to insects (Heath et al. 1997; Koiwa et al. 1997) and wounding (Lee et al. 1986). Bdi, a homolog of BCI-9 (Wei et al. 2002), is in the chemically induced family; it is induced by 2,6-dichloroisonicotinic acid and leads to increased resistance to the powdery mildew (Besser et al. 2000).
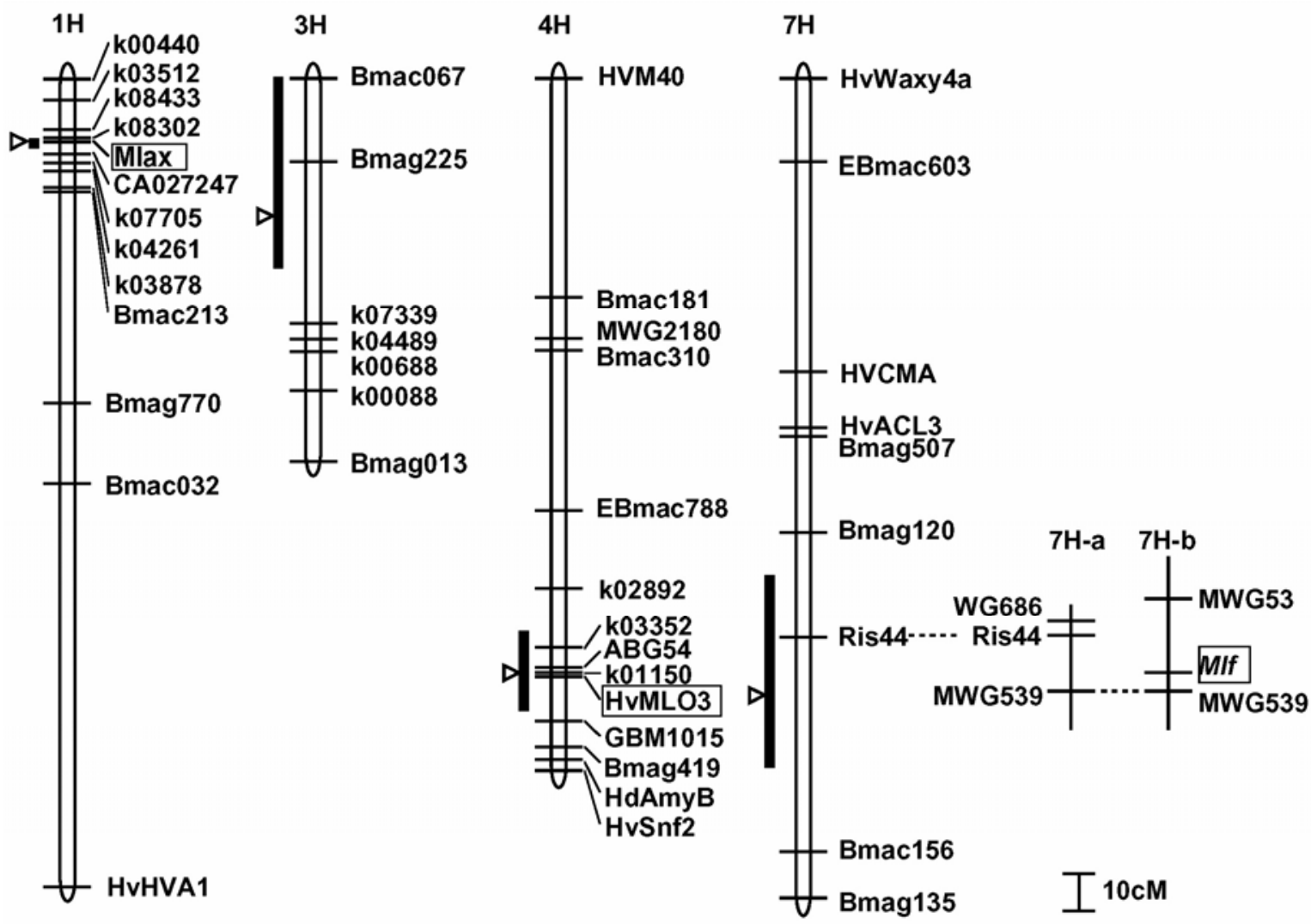

Fig. 5. Positions of blast resistance quantitative trait loci (QTL) detected on barley chromosomes $1 \mathrm{H}, 3 \mathrm{H}$, $4 \mathrm{H}$, and $7 \mathrm{H}$ in the doubled haploid progeny derived from the $\mathrm{F}_{1}$ of BCD $47 \times$ Baronesse. QTL peaks and 1-LOD (log of the likelihood ratio) support intervals are shown by open triangles and black bars, respectively. Mildew-resistance loci are surrounded by boxes. $7 \mathrm{H}$-a and $7 \mathrm{H}-\mathrm{b}$ are parts of the restriction fragment length polymorphism maps of chromosome 7H constructed by Graner and associates (1994) and Schönfeld and associates (1996), respectively.

Table 3. Mildew resistance loci colocated with quantitative trait loci (QTL) conferring resistance to rice blast isolates in barley

\begin{tabular}{|c|c|c|c|c|c|}
\hline \multirow[b]{2}{*}{ Chromosome } & \multicolumn{2}{|c|}{ Mildew resistance locus } & \multicolumn{2}{|c|}{ Blast resistance QTL } & \multirow[b]{2}{*}{ Note } \\
\hline & Name & Closest marker $^{a}$ & Barley cultivar & Marker interval & \\
\hline $1 \mathrm{H}$ & Mla & & Baronesse & $\operatorname{Mlax}^{\mathrm{d}}$ & $\begin{array}{l}\text { Mlax is an sequence-tagged site marker developed based on } \\
\text { the sequence of Mla12. Baronesse hasMla } 3^{\mathrm{g}}\end{array}$ \\
\hline $2 \mathrm{H}$ & Mlhb & MWG682 (0 cM) $)^{\mathrm{b}}$ & TR306 & $\begin{array}{l}\text { MWG844 to } \\
\text { ABG058 }\end{array}$ & $\begin{array}{l}\mathrm{ABG} 058 \text { is located at the same position as MWG } 682 \text { on the } \\
\text { map of Hordeum-NABGMP2 }\end{array}$ \\
\hline $4 \mathrm{H}$ & Mlg & & TR306 & $\mathrm{dMlg}$ to $\mathrm{ABG} 715^{\mathrm{f}}$ & dMlg is $M l g$. TR306 does not have $M l g^{\mathrm{i}}$ \\
\hline $4 \mathrm{H}$ & mlo & & $\begin{array}{l}\text { BCD47 } \\
\text { TR306 }\end{array}$ & $\begin{array}{l}\text { k01150 to HvMLO3 } \\
\text { ABG366 to ABG601 }\end{array}$ & $\begin{array}{l}\text { HvMLO3 is a simple sequence repeat marker based on } m l o^{\mathrm{j}} \\
\text { ABG366 is } 0.7 \mathrm{cM} \text { from } m l o^{\mathrm{k}} \text {. } \\
\text { Neither BCD } 47 \text { nor TR } 306 \text { have } m l o\end{array}$ \\
\hline
\end{tabular}

${ }^{a}$ Genetic distances between mildew resistance loci and DNA markers are in parenthesis.

b Pickering (1995).

c Schönfeld et al. (1996).

d This study.

e Chen et al. 2003.

${ }^{\mathrm{f}}$ Sato et al. 2001.

g Hovmøller et al. 2000; Dreiseitl 2003.

${ }^{\mathrm{h}}$ GrainGenes database.

i Spaner et al. 1998.

j Ramsay et al. 2000.

${ }^{\mathrm{k}}$ Büschges et al. 1997. 
As a first step toward establishing candidate genes for $R M o 1$ in barley, we asked the question, "Are there any rice blast resistance genes or genes conferring resistance to other pathogens in the syntenous region of rice?" We established colinearity of gene order between a $23.5-\mathrm{cM}$ region of barley chromosome $1 \mathrm{H}$ containing $R M o 1$ and a $510-\mathrm{kb}$ region at the end of rice chromosome 5 . The $510-\mathrm{kb}$ syntenous region contains the bacterial blight resistance gene $x a 5$. According to one of the models proposed by Iyer and McCouch (2004), TFIIA $\gamma$ - the product of $x a 5$-functions as a virulence target via interaction with the Avrxa5 protein. The complex of the two molecules is then detected by a third factor, such as an $R$ gene, and this initiates a signaling pathway that leads to bacterial blight resistance. A similar scenario, based on the 'guard hypothesis' (van der Biezen and Jones 1998), can be applied to the case of RMo1. However, since we detected no barley ortholog of $x a 5$ in the published 261-kb sequence of the short arm of barley $1 \mathrm{H}$, additional experiments will be needed to confirm the candidacy of this gene for RMol.

Four blast resistance QTL were identified in Baronesse and BCD47. Interestingly, the largest-effect QTL, in which Baronesse contributed the favorable allele, was detected at the same position as RMo1, which cosegregates with Mla. Two of the other QTL, in which BCD47 contributes the resistance allele, were also coincident with the positions of mildew resistance genes, the mlo locus on chromosome $4 \mathrm{H}$ and the Mlf locus on chromosome $7 \mathrm{H}$. In total, at least five blast resistance QTL map to the same genomic regions as mildew resistance genes; we previously reported the association of mildew resistance loci and barley blast resistance QTL for $M l g, m l o$, and Mlhb in the Harrington $\times$ TR306 mapping population (Chen et al. 2003; Sato et al. 2001) (Table 3). Mla is a CC-NBS-LRR $R$ gene, colocated with other $R$ gene family members and with $R M o 1$. Blast resistance major genes, QTL, and NBS-LRR $R$ gene clusters are also reported in rice (Wisser et al. 2005). Thus, members of the NBS-LRR $R$ gene cluster could differentiate as major genes, i.e., RMo1 and as QTL alleles for blast resistance.

The $4 \mathrm{H}$ blast resistance QTL is coincident with $M l o$, which functions as a negative regulator of broad spectrum disease resistance to powdery mildew and spontaneous leaf-cell death (Büschges et al. 1997). Homozygous mutations in Mlo confer race-nonspecific resistance to the powdery mildew and enhanced susceptibility to the rice blast fungus (Jarosch et al. 1999). The basis of the contrasting responses to different pathogens is not known. It has been suggested that Mlo functions as a key element of basal pathogen resistance and the durable re- sistance to the powdery mildew fungus due to the mlo mutations are exceptional events that alter this basal response (Jarosch et al. 2003). If the degree of the basal resistance conferred by Mlo alleles varies, it is possible that the effects of these alleles could be manifested as rice blast resistance QTL or QTL associated with other diseases. In the same BCD47 $\times$ Baronesse population, we have detected a large-effect QTL associated with stripe rust (incited by Puccinia striiformis $\mathrm{f}$. sp. hordei), and this QTL is coincident with the rice blast resistance QTL and Mlo (Vales et al. 2005). For both diseases, BCD47 confers the resistance allele.

A few rice homologs of barley Mlo have been isolated and characterized (Elliott et al. 2002; Kim et al. 2002b). One of these, OsMlo2, is on the end of chromosome 3 (Elliott et al. 2002), and according to the TIGR rice genome database, OsMlo2 (Os03g03700) is located within the intervals defined by RG104 (Os03g01780) and RG409 (Os03g06900). Blast, sheath blight, and bacterial blight resistance QTL have been reported in this same interval ( $\mathrm{Li}$ et al. 1995, 1999; Wang et al. 1994). This suggests that the rice and barley orthologs of Mlo could both have pleiotropic effects in conferring quantitative resistance to multiple pathogens or that there is a conservation of multiple linked resistance loci in the two species. Support for the former is the observation that both barley and rice Mlo genes interact with calmodulin, which is a ubiquitous $\mathrm{Ca}^{2+}$ binding protein mediating defense-associated $\mathrm{Ca}^{2+}$ signals (Kim et al. 2002a and b). In both cases, the genes were rapidly induced in young leaves or suspension cells after treatment with blast fungus spores (Kim et al. 2002b; Piffanelli et al. 2002).

The structure and function of $M l g, M l h b$, and $M l f$ have not been determined, but the linkage relationships of these mildew resistance genes with other quantitative and qualitative resistance genes have been reported. For instance, a QTL for powdery mildew resistance was detected at the same location as Mlg (Spaner et al. 1998), and Mlhb maps to the same position as Rph.Hb, a major gene conferring leaf rust resistance (Pickering et al. 1998). This suggests that Mlg, Mlhb, and Mlf are members of resistance-gene complexes, similar to Mla region. Therefore, at this point, it is not possible to determine if the blast resistance QTL we report are pleiotropic effects of the mildew resistance genes or the effects of linked genes.

We have added and mapped a major gene to the list initiated by Yaegashi (1988), and we have corroborated and expanded on our previous reports of resistance QTL in barley that confer resistance to multiple races of the pathogen (Chen et al. 2003; Sato et al. 2001). The colocation of these qualitative and quan-

Table 4. Primer sequences for eight additional barley expressed sequence tag-based markers and corresponding restriction enzymes used for CAPS-based markers

\begin{tabular}{|c|c|c|c|}
\hline Marker & Type $^{\mathbf{a}}$ & Primer sequences ( $\left(5^{\prime}\right.$ to $\left.3^{\prime}\right)$ & Restriction enzyme \\
\hline \multirow[t]{2}{*}{ k00440 } & Indel & CGGACAATTTGGTTGTTTCC & \\
\hline & & GGAAGACACGGTGCAAAAAT & \\
\hline \multirow[t]{2}{*}{ k04230 } & Indel & CAAGCAAATCCTCACTGCAA & \\
\hline & & GACCTCAAGTCGTACCTGGC & \\
\hline \multirow[t]{2}{*}{ CA027247 } & Indel & CTGGGGTGAACAGGAGAGAG & \\
\hline & & CGTTCTTCATGTCGAAGCAG & \\
\hline \multirow[t]{2}{*}{ BU995493 } & CAPS & CATTGTTGTGCCAGATACCG & HaeIII \\
\hline & & GCTGGGAGATATCCAGACCA & \\
\hline \multirow[t]{2}{*}{ k10955 } & CAPS & TACAACTTCAAGATCCCCGC & $R s a \mathrm{I}$ \\
\hline & & GGATGGCTATGTCGCTTGAT & \\
\hline \multirow[t]{2}{*}{ k03671 } & CAPS & CATAGGGCTGTCCGTTTGTT & DdeI \\
\hline & & CAAGTTTGATATCGAGCGCA & \\
\hline \multirow[t]{2}{*}{ k07705 } & CAPS & AGGGTAGGAGGCCATCTTGT & RsaI \\
\hline & & GACGGCAAGAAGAGCGAGT & \\
\hline \multirow[t]{2}{*}{ k03520 } & CAPS & TTCTTTACACGTCTGGCACG & $S p h \mathrm{I}$ \\
\hline & & AAGGTGAAGGAACACCAACG & \\
\hline
\end{tabular}

\footnotetext{
${ }^{\mathrm{a}}$ Indel $=$ insertion and deletion, CAPS $=$ cleaved amplified polymorphic sequence.
} 
titative blast resistance genes with mildew-resistance genes merits further investigation. Information on the blast resistance genes in barley is not currently of economic importance, because barley is usually not cultivated in rotation with rice and in the moist, warm conditions conducive to blast disease development. However, if barley acreage were to expand or shift in response to global warming or other factors, the location and linkage relationships of these genes could be of significant importance. Likewise, information on these genes could be of value to rice breeders and geneticists.

\section{MATERIALS AND METHODS}

\section{Plant materials and inoculation tests.}

A set of 100 doubled haploid (DH) lines derived from the cross BCD $47 \times$ Baronesse (Vales et al. 2005) was used for this study. BCD47 is a DH experimental line developed at Oregon State University (Corvallis, U.S.A.), and Baronesse is a cultivar of German origin. Baronesse has the Mla3 gene conferring complete resistance to powdery mildew (Dreiseitl 2003; Hovmøller et al. 2000) but no resistance alleles at the Mlf and $m l o$ loci. BCD47 does not possess any resistance genes at the Mla, Mlf, and mlo loci.

The Canadian cultivar Harrington, a second experimental DH line (BCD12), and two Japanese rice cultivars, Aichi asahi and Shin2, were used as susceptible controls. The Japanese rice blast isolates Ken 54-20 (003.0) and Ken 53-33 (137.1) were obtained from the collection maintained at the former Paddy Crop Disease Laboratory at the National Agriculture Research Center, Tsukuba, Japan. For disease phenotyping, five seeds of each cultivar or line were sown in each of 18 rows in a plastic tray and were grown in a glasshouse. Seedlings were inoculated at the 1.5- to 2-leaf stage by spraying a conidial suspension containing $5 \times 10^{4}$ spores $/ \mathrm{ml}$ onto the leaves. The inoculated plants were incubated in a moist chamber at $25^{\circ} \mathrm{C}$ for $16 \mathrm{~h}$ and, then, were transferred to the glasshouse. Six days after inoculation, disease severity of the second leaf of each seedling was rated on a 0 to 5 scale in which $0=$ no symptom, $1=$ percentage of diseased leaf area (DLA) $<1 \%, 2=$ $1 \%<$ DLA $<5 \%, 3=5 \%<$ DLA $<10 \%, 4=10 \%<$ DLA $<$ $50 \%$, and $5=$ DLA $>50 \%$.

\section{Linkage, QTL, and sequence analysis.}

The marker data set for the linkage maps generated by Vales and associates (2005) was used for linkage analysis. Eight additional EST markers developed based on the sequences of barley cDNA clones were added to the data set and were mapped: k00440, k04230, CA027247, BU995493, k10955, k03671, $\mathrm{k} 07705$, and $\mathrm{k} 03520$. Primer sequences for these new EST markers are shown in Table 4 . The polymerase chain reaction (PCR) condition for all markers was $94^{\circ} \mathrm{C}$ for $2 \mathrm{~min}, 5$ cycles of $94^{\circ} \mathrm{C}$ for $30 \mathrm{~s}, 65^{\circ} \mathrm{C}$ for $30 \mathrm{~s}$, decreasing $1^{\circ} \mathrm{C}$ per cycle, and $72^{\circ} \mathrm{C}$ for $2 \mathrm{~min}, 35$ cycles of $94^{\circ} \mathrm{C}$ for $30 \mathrm{~s}, 60^{\circ} \mathrm{C}$ for $30 \mathrm{~s}$, and $72^{\circ} \mathrm{C}$ for $2 \mathrm{~min}$, and $72^{\circ} \mathrm{C}$ for $7 \mathrm{~min}$. PCR product size polymorphisms were scored directly after electrophoresis on $13 \%$ acrylamide gels at a constant voltage of $250 \mathrm{~V}$ for $7 \mathrm{~h}$, using a high-efficiency genome-scanning system (Hori et al. 2003). In cases in which there were no clear length polymorphisms for PCR products, they were digested with the restriction enzymes listed in Table 1 and the samples were electrophoresed on 3\% agarose gels. MAPMAKER/EXP ver. 3.0 (Lander et al. 1987) was used for linkage analysis with the Haldane mapping function (Haldane 1919). QTL analysis was conducted by the composite interval mapping procedures of QTL Cartographer ver. 2.5 (Wang et al. 2005). Linkage groups were scanned at 0.5$\mathrm{cM}$ intervals, and the linkage probability of QTL for each interval was expressed as a LOD score. Type I 5\% thresholds for
LOD scores, estimated based on 1,000 permutations, were used to declare QTL significance. For sequence analysis, standard nucleotide-nucleotide (blastn; Altschul et al. 1997) searches were performed against the National Center for Biotechnology Information nonredundant database and the TIGR Rice Genome Annotation database.

\section{LITERATURE CITED}

Altschul, S. F., Madden, T. L., Schaffer, A. A., Zhang, J., Zhang, Z., Miller, W., and Lipman, D. J. 1997. Gapped BLAST and PSI-BLAST: A new generation of protein database search programs. Nucleic Acids Res. 25:3389-3402.

Besser, K., Jarosch, B., Langen, G., and Kogel, K. H. 2000. Expression analysis of genes induced in barley by chemical activation reveals distinct disease resistance pathways. Mol. Plant Pathol. 1:277-286.

Büschges, R., Hollricher, K., Panstruga, R., Simons, G., Wolter, M., Frijters, A., van Daelen, R., van der Lee, T., Diergaarde, P., Groenendijk, J., Töpsch, S., Vos, P., Salamini, F., and Schulze-Lefert, P. 1997. The barley Mlo gene: A novel control element of plant pathogen resistance. Cell 88:695-705.

Chen, H, Wang, S, Xing, Y, Xu, C, Hayes, P. M., and Zhang, Q. 2003. Comparative analyses of genomic locations and race specificities of loci for quantitative resistance to Pyricularia grisea in rice and barley. Proc. Natl. Acad. Sci. U.S.A. 100:2544-2549.

Couch, B. C., and Kohn, L. M. 2002. A multilocus gene genealogy concordant with host preference indicates segregation of a new species, Magnaporthe oryzae, from M. grisea. Mycologia 94:683-693.

Dreiseitl, A. 2003. Adaptation of Blumeria graminis f. sp. hordei to barley resistance genes in the Czech Republic in 1971-2000. Plant Soil Environ. 49:241-248.

Graner, A., Bauer, E., Kellermann, A., Kirchner, S., Muraya, J. K., Jahoor, A., and Wenzel G. 1994. Progress of RFLP-map construction in winter barley. Barley Genet. Newsl. 23:53-59.

Elliott, C., Zhou, F., Spielmeyer, W., Panstruga, R., and Schulze-Lefert, P. 2002. Functional conservation of wheat and rice Mlo orthologs in defense modulation to the powdery mildew fungus. Mol. Plant-Microbe Interact. 15:1069-1077.

Haldane, J. B. S. 1919. The combination of linkage values and the calculation of distances between the loci of linked factors. J. Genet. 8:299-309.

Hammond-Kosack, K. E., and Parker, J. E. 2003. Deciphering plantpathogen communication: Fresh perspectives for molecular resistance breeding. Curr. Opin. Biotechnol. 14:177-193.

Hanson, W. D. 1959. Minimum family sizes for the planning of genetic experiments. Agron. J. 51:711-715.

Heath, R. L., McDonald, G., Christeller, J. T., Lee, M., Bateman, K., West, J., Van Heeswijck, R., and Anderson, M. A. 1997. Proteinase inhibitors from Nicotiana alata enhance plant resistance to insect pests. J. Insect Physiol. 43:833-842.

Hori K., Kobayashi, T., Shimizu, A., Sato, K., Takeda, K., and Kawasaki, S. 2003. Efficient construction of high-density linkage map and its application to QTL analysis in barley. Theor. Appl. Genet. 107:806-813.

Hovmøller, M. S., Caffier, V., Jalli, M., Andersen, O., Besenhofer, G., Czembor, J. H., Dreiseitl, A., Felsenstein, F., Fleck, A., Heinrics, F., Jonsson, R., Limpert, E., Mercer, P., Plesnik, S., Rashal, I., Skinnes, H., Slater, S., and Vronska, O. 2000. The European barley powdery mildew virulence survey and disease nursery 1993-1999. Agronomie 20:729-743.

Iyer, A. S., and McCouch, S. R. 2004. The rice bacterial blight resistance gene $x a 5$ encodes a novel form of disease resistance. Mol. PlantMicrobe Interact. 17:1348-1354.

Jarosch, B., Kogel, K-H., and Schaffrath, U. 1999. The ambivalence of the barley Mlo locus: Mutations conferring resistance against powdery mildew (Blumeria graminis f. sp. hordei) enhance susceptibility to the rice blast fungus Magnaporthe grisea. Mol. Plant-Microbe Interact. 12:508-514.

Jarosch, B., Jansen, M., and Schaffrath, U. 2003. Acquired resistance functions in mlo barley, which is hypersusceptible to Magnaporthe grisea. Mol. Plant-Microbe Interact. 16:107-114.

Kawai, T., Kitamura, Y., Ootani, H., and Watanabe, K. 1979. Studies on the cultivations of summer sowing barley 3. Peculiarity in the occurrence of diseases and insect pests. Kinki Chugoku Agr. Res. 58:38-41 (in Japanese).

Kim, M. C., Panstruga, R., Elliott, C., Muller, J., Devoto, A., Yoon, H. W., Park, H. C., Cho, M. J., and Schulze-Lefert, P. 2002a. Calmodulin interacts with MLO protein to regulate defence against mildew in barley. Nature 416:447-451. 
Kim, M. C., Lee, S. H., Kim, J. K., Chun, H. J., Choi, M. S., Chung, W. S., Moon, B. C., Kang, C. H., Park, C. Y., Yoo, J. H., Kang, Y. H., Koo, S. C., Koo, Y. D., Jung, J. C., Kim, S. T., Schulze-Lefert, P., Lee, S. Y., and Cho, M. J. 2002b. Mlo, a modulator of plant defense and cell death, is a novel calmodulin-binding protein: Isolation and characterization of a rice Mlo homologue. J. Biol. Chem. 277:1930419314.

Koiwa, H., Bressan, R. A., and Hasegawa, P. M. 1997. Regulation of proteinase inhibitors and plant defense. Trends Plant Sci. 2:379-384.

Lander, E. S., Green, P., Abrahamson, J., Barlow, A., and Daly, M. J. 1987. MAPMAKER: An interactive computer package for constructing primary genetic linkage maps of experimental and natural populations. Genomics 1:174-181.

Lee, J. S., Brown, W. E., Graham, J. S., Pearce, G., Fox, E. A., Dreher, T.W., Ahern, K. G., Pearson, G. D., and Ryan, C. A. 1986. Molecular characterization and phylogenetic studies of a wound-inducible proteinase inhibitor I gene in Lycopersicon species. Proc. Natl. Acad. Sci. U.S.A. 83:7277-7281.

Li, Z., Pinson, S. R. M., Marchetti, M. A., Stansel, J. W., and Park, W. D. 1995. Characterization of quantitative trait loci (QTLs) in cultivated rice contributing to field resistance to sheath blight (Rhizoctonia solam). Theor. Appl. Genet. 91:382-388.

Li, Z. K., Luo, L. J., Mei, H. W., Paterson, A. H., Zhao, X. H., Zhong, D. B., Wang, Y. P., Yu, X. Q., Zhu, L., Tabien, R., Stansel, J. W., and Ying, C. S. 1999. A "defeated" rice resistance gene acts as a QTL against a virulent strain of Xanthomonas oryzae pv. oryzae. Mol. Gen. Genet. 261:58-63.

Matsumoto, S., and Mogi, S. 1979. Ear blast disease of late-summer sown barley. Proc. Assoc. Pl. Prot. Kyushu 25:12-14 (in Japanese).

Miura, Y., Ding, C., Ozaki, R., Hirata, M., Fujimori, M., Takahashi, W., Cai, H., and Mizuno, K. 2005. Development of EST-derived CAPS and AFLP markers linked to a gene for resistance to ryegrass blast (Pyricularia sp.) in Italian ryegrass (Lolium multiflorum Lam.). Theor. Appl. Genet. 111:811-818.

Pickering, R. A., Hill, A. M., Michel, M., and Timmerman-Vaughan, G. M. 1995. The transfer of a powdery mildew resistance gene from Hordeum bulbosum L. to barley (H. vulgare L.) chromosome 2 (2I). Theor. Appl. Genet. 91:1288-1292.

Pickering, R. A., Steffenson, B. J., Hill, A. M., and Brovkova, I. 1998. Association of leaf rust and powdery mildew resistance in a recombinant derived from a Hordeum vulgare $\times$ Hordeum bulbosum hybrid. Plant Breed. 117:83-84.

Piffanelli, P., Zhou, F., Casais, C., Orme, J., Jarosch, B., Schaffrath, U., Collins, N. C., Panstruga, R., and Schulze-Lefert, P. 2002. The barley MLO modulator of defense and cell death is responsive to biotic and abiotic stress stimuli. Plant Physiol. 129:1076-1085.

Qu, S., Liu, G., Zhou, B., Bellizzi, M., Zeng, L., Dai, L., Han, B., and Wang, G.-L. 2006. The broad-spectrum blast resistance gene Pi9 encodes an NBS-LRR protein and is a member of a multigene family in rice. Genetics 172:1901-1914.

Ramsay, L., Macaulay, M., degli Ivanissevich, S., MacLean K., Cardle, L., Fuller, J., Edwards, K. J., Tuvesson, S., Morgante, M., Massari, A., Maestri, E., Marmiroli, N., Sjakste, T., Ganal, M., Powell, W., and Waugh, R. 2000. A simple sequence repeat-based linkage map of barley. Genetics 156:1997-2005.

Routledge, A. P. M., Shelley, G., Smith, J. V., Talbot, N. J., Draper, J., and Mur, L. A. J. 2004. Magnaporthe grisea interactions with the model grass Brachypodium distachyon closely resemble those with rice (Oryza sativa). Mol. Plant Pathol. 5:253-265.

Sato, K., Inukai, T., and Hayes, P. M. 2001. QTL analysis of resistance to the rice blast pathogen in barley (Hordeum vulgare). Theor. Appl. Genet. 102:916-920.

Schönfeld, M., Ragni, A., Fischbeck, G., and Jahoor, A. 1996. RFLP mapping of three new loci resistance for resistance genes to powdery mildew (Erysiphe graminis f. sp. hordei) in barley. Theor. Appl. Genet. 93:48-56.

Spaner D., Shugar L. P., Choo T. M., Falak I., Briggs K. G., Legge W. G., Falk D. E., Ullrich S. E., Tinker N. A., Steffenson B. J., and Mather, D. E. 1998. Mapping of disease resistance loci in barley on the basis of visual assessment of naturally occurring symptoms. Crop Sci. 38:843-850.

Urashima, A. S., Lavorenti, N. A., Goulart, A. C. P., and Mehta, Y. R. 2004. Resistance spectra of wheat cultivars and virulence diversity of Magnaporthe grisea isolates in Brazil. Fitopatologia Brasileira 29:511-518.

Vales, M. I., Schön, C. C., Capettini, F., Chen, X. M., Corey, A. E., Mather, D. E., Mundt, C. C., Richardson, K. L., Sandoval-Islas, J. S., Utz, H. F., and Hayes, P. M. 2005. Effect of population size on the estimation of QTL: A test using resistance to barley stripe rust. Theor. Appl. Genet. 111:1260-1270.

van der Biezen, E. A., and Jones, J. D. 1998. Plant disease-resistance proteins and the gene-for-gene concept. Trends Biochem. Sci. 23:454-456.

Wang, G. L., Mackill, D. J., Bonman, J. M., McCouch, S. R., Champoux, M. C., and Nelson, R. J. 1994. RFLP mapping of genes conferring complete and partial resistance to blast in a durably resistant rice cultivar. Genetics 136:1421-1434.

Wang, Z. X., Yano, M., Yamanouchi, U., Iwamoto, M., Monna, L., Hayasaka, H., Katayose, Y., and Sasaki, T. 1999. The Pib gene for rice blast resistance belongs to the nucleotide binding and leucine-rich repeat class of plant disease resistance genes. Plant J. 19:55-64.

Wang S., Basten, C. J., and Zeng, Z.-B. 2005. Windows QTL Cartographer version 2.5. Department of Statistics, North Carolina State University, Raleigh, NC, U.S.A. Published online.

Wei, F., Wing, R. A., and Wise, R. P. 2002. Genome dynamics and evolution of the Mla (Powdery Mildew) resistance locus in barley. Plant Cell 14:1903-1917.

Williams, D. W., Burrus, P. B., and Vincelli, P. 2001. Severity of gray leaf spot in perennial ryegrass as influenced by mowing height and nitrogen level. Crop Sci. 41:1207-1211.

Williams, K. J. 2003. The molecular genetics of disease resistance in barley. Aust. J. Agric. Res. 54:1065-1079.

Wisser, R. J., Sun, Q., Hulbert S, H., Kresovich, S., and Nelson, R. J. 2005. Identification and characterization of regions of the rice genome associated with broad-spectrum, quantitative disease resistance. Genetics 169:2277-2293.

Yaegashi, H. 1988. Inheritance of blast resistance in two-rowed barley. Plant Dis. 72:608-610.

\section{AUTHOR-RECOMMENDED INTERNET RESOURCES}

GrainGenes database: wheat.pw.usda.gov/GG2/index.shtm

The Institute for Genomic Research (TIGR) Rice Genome Annotation database: www.tigr.org/tdb/e2k1/osa1/

National Center for Biotechnology Information nonredundant database: www.ncbi.nlm.nih.gov/BLAST 